\title{
Northern Ireland's 1968 at 50: Agonism and Protestant Perspectives on Civil Rights
}

\section{Introduction}

On 5 October 1968, a banned but peaceful Civil Rights march was attacked by the Royal Ulster Constabulary (RUC) in Derry/Londonderry's Duke Street. Though historians and protagonists have highlighted the provocative intentions of some of the protestors, ${ }^{1}$ the heavy-handed repression of this second attempt to bring the issue of discrimination and inequality to the streets of Northern Ireland was captured by television cameras and subsequently triggered the beginning of the province's "1968", ${ }^{2}$ with the Civil Rights movement at front and centre. ${ }^{3}$ Over the course of the next three months, momentum gathered, eventually forcing the then Prime Minister Terence O'Neill to yield on a number of key demands. However, pressure from elements of Unionism, who felt that too much ground had been conceded, and some Nationalists, who thought that pushing for more was the way forward, came to a head on Burntollet bridge on 4 January 1969. ${ }^{4}$ This infamous attack on the People's Democracy (PD) 'Long March' from Belfast to Derry/Londonderry effectively marked the end of the street politics that had taken hold. From this point on, Northern Ireland was on set on an irreversible course that would see it spiral uncontrollably towards the conflict known as the 'Troubles'. In the recent and complex history of the province, 1968 and the Civil Rights era (albeit brief) is understandably pivotal. ${ }^{5}$ However, the focus of this article is the conflicted and fragmented memory of the civil rights movement and its agitation - among those traditionally viewed as the principal communal opposition to the radicalism, militancy and fervour of 1968: Ulster Protestants. It is a legacy which continues in the form of an ongoing and fragile Peace Process.

The fiftieth anniversary of 1968 marked an important turning point in how it is presented and remembered. The move to incorporate previously marginalised Protestant perspectives, as demonstrated in particular through the example of a collaborative project at Belfast's Ulster Museum, is indicative of the timeliness and effectiveness of an agonistic approach to dealing with Northern Ireland's contested and challenging past. Beginning with an assessment of how and why this period has commonly become exclusively associated with one side of the divide, there then follows an overview of Protestant perspectives. Drawing on a range of oral testimonies, it will be argued that the latter's absence merits a 
certain problematisation. A brief unpacking of the notions of 'antagonistic, 'cosmopolitan' and 'agonistic' remembering then provides the necessary background to understand how this process provides a well-timed and cogent blueprint for managing the difficult legacy of the province's past.

\section{The dominant discourse: A Catholic story}

It is of no surprise that the most common assumption made about Northern Ireland's 1968 is that it is a story that belongs to the Catholic/Nationalist/ Republican (CNR) community. ${ }^{6}$ Given the fact that this period is most commonly associated with the question of Civil Rights and the struggle that took place, one can easily understand why it is that the majority of people associate what happened with the section of the population that was most seeking to challenge the discrimination of the time. Inequalities were greatly determined by the Catholic/Protestant binary that in a broad sense characterises the divisions that lay, and arguably continue to lie, at the root of the problems. Catholics were losing out in terms of housing, employment and voting rights, with the state perceived to have been set up to benefit only the Protestant community. ${ }^{7}$ Though there is nuance to these well-worn historical debates, ${ }^{8}$ the campaign logically grew out of the CNR community and was spearheaded by a range of people mostly from within. It stands to reason, therefore, that in subsequent years the nature of the memory of this period and its legacy has equally been dominated by one side.

This is not to say that there has been a comparable attempt by the CNR community to explicitly stake its claim on this period in the same manner as has been the case in other parts of the world. It has been demonstrated and explained elsewhere how, in the aftermath of "1968", in the Northern Irish context, there was little in the way of a similar clamour to take ownership. In fact, because of the onset of the Troubles in the immediate aftermath, there was no real desire by anyone to 'own' the legacy of the Civil Rights era in the same manner as had been the case in places such as France where its "1968" almost immediately became a cause for celebration. ${ }^{9}$ The memory of Northern Ireland's 1968 took a different trajectory and was effectively buried. This is one of the main reasons why, in transnational perspectives of 1968, Northern Ireland rarely features. ${ }^{10}$ However, since 1998 and the onset of peace, circumstances in Northern Ireland have changed, leading to all sorts of developments, including in relation to perspectives on the past. The events of 1968 
provide a potent example of how such significant contextual shifts pave the way for the recalibration of memories of important events and open up new broader possibilities on the question of Northern Ireland's contested past. ${ }^{11}$

If one considers for example the first peace-time commemoration of the 1968 events in Northern Ireland that took place on their $40^{\text {th }}$ anniversary in 2008 , the change is irrefutable. ${ }^{12}$ For the first time, '1968' was given the same commemorative treatment that had become customary in other nations that experienced similar upheaval. A whole plethora of events (such as conferences, workshops, film screenings, and concerts) were organised to celebrate this anniversary. ${ }^{13}$ Former participants felt more at ease to come out and tell their stories. There was a genuine attempt to look at this period from a more positive perspective and, importantly, explicit efforts were made to stitch Northern Ireland into the transnational narrative and vice versa. The $40^{\text {th }}$ anniversary demonstrated just how the ending of the conflict enabled significant developments that have contributed to the process of the Northern Irish events being brought in line with their international counterparts.

However, despite such developments, the one-sidedness of the story remained: there was little or nothing in the way of Protestant perspectives. The anniversary events were formulated and run mainly by a committee dominated by the Social Democratic and Labour Party (SDLP), who set out to tell their story of how the Civil Rights era should be remembered, and very much from the CNR perspective. ${ }^{14}$ There was no real space for inclusive discussion or debate that would have provided the grounds for a consideration of alternative narratives, thus consolidating the idea that this was and should remain a Catholic story. The only debates of any substance that appeared to take place were not between the communities, but within them. For example, the enthusiasm with which the moderate Irish nationalist SDLP set out to take control of this $40^{\text {th }}$ anniversary was interpreted by some as resulting from their concerns over Sinn Féin attempts to wrestle away ownership of its legacy. As Bernadette McAliskey explained:

Part of it is laying claim. Sinn Féin have no Civil Rights past, the Provos [Provisional IRA] weren't there, they were not formed until 1970, but it is important for them, just as it was important for them to build their republican credentials. They have to establish the link from ' 68 to '72. In doing that they cut across the poor old Social Democrats [SDLP] who didn't exist at the time either, they also come in ' 70 but being slightly older, more of their membership can claim individual heritage, so that is where the battle started. ${ }^{15}$ 
Since winding down the armed struggle, Sinn Féin has sought to incorporate the Civil Rights period as part of its justification for the Irish Republican Army (IRA) conflict of the Troubles. The argument runs that having attempted to bring about equality and justice through the peaceful means of the Civil Rights campaign, the Nationalist community, with the IRA as its main expression, was left with no alternative but the turn to violence in the face of the brutal repression doled out by the state. The SDLP rejected (and continues to reject) such a narrative, claiming that they were the only true party of the Civil Rights movement. As a founding member explained:

I very much felt that the people involved in the Commemorative committee had to do what they did. Otherwise others would have taken over. [...] I mean the rewriting of history has to be combated. ${ }^{16}$

Another SDLP founder waded in to challenge what he called a 'hijacking' of historical events 'which are not attributable to them [Sinn Féin] at all. How can you be involved in civil rights activity when you are involved in killings?'17 In this interpretation, the 'men of violence' were not part of the Civil Rights movement and in fact undermined its potential to bring about acceptable reforms that would have improved the lives of many and potentially avoided the slaughter of the subsequent 30-year conflict. Denis Haughey outlined his perspective:

Some people in Sinn Féin accused us all of being in a SDLP plot of taking over the legacy of the Civil Rights Movement, the absurdity of that I think led to its dying quickly, because how can you challenge the fact that John Hume was the major figure in the Civil Rights movement, that Austin Currie led the first Civil Rights march, that Ivan Cooper was chair of the citizens action committee, that Bríd Rogers led the first Civil Rights march in Lurgan, that I was chair of the Tyrone Civil Rights association? It was just absurd. ${ }^{18}$

Another interesting and noteworthy debate from within the Nationalist community took place between what could be described as the moderate and radical elements of the Civil Rights movement. This was aptly exemplified on the 22 November 2008 when the official Civil Rights Commemoration Committee hosted a quite extravagant and formal conference in Derry's Guildhall with a whole plethora of invited guests including the then Irish President Mary McAleese. ${ }^{19}$ At the same time and in the same city, in Sandino's Bar, an alternative conference was organised by a group of former activists who refused to take 
part in the formal commemorative conference. ${ }^{20}$ One of the radical activist attendees explained this split:

The Civil Rights movement view was that there was [sic] these worthy people who were wives of doctors and MPs who had campaigned [...] for democracy in Ulster who were aware of injustices and who did things about it. Then there was the view that an ill-disciplined mob came along, but the 40th anniversary is tending to remember the worthy people and wanting to talk about them and the fact that [Mary] McAleese became president and Mary Robinson worked in the United Nations - they want to do that. Whereas I wanted to remember the gangs of people who turned out and went on marches. ${ }^{21}$

That the 1968 events had in 2008 become the focus of such a commemorative surge and the site of interesting debates such as those outlined above is indicative of the positive steps brought about by the conclusion of the conflict. However, despite such developments, little progress was made in breaking the one-sided nature of how the story was told. The $40^{\text {th }}$ anniversary confirmed that the Civil Rights era, in popular memory, belonged to only the Catholic community. As will be argued in the next section, such a myopic perspective falls short of telling the full story - particularly when one considers the extent, range and importance of contributions of the Protestant community to these pivotal events.

\section{The Protestant Perspective: A marginalised narrative}

The marginalisation of the Protestant perspective on how this period is remembered, however understandable, is an error. The idea that we can truly understand the nature of what happened without taking into consideration the contribution of all those involved would appear to be obvious. This is all the more the case when one considers the unquestionably pivotal influence those from the Protestant/Unionist/Loyalist (PUL) community had in defining the characteristics of this period. ${ }^{22}$ The fact that the popular memory of such a pivotal moment in the recent past has been constructed in such a constrained fashion, based almost exclusively on the Catholic perspective, is a potent example of just how the past is all too often a central factor in the perpetuation of the divisions that lie at the heart of the problems that have afflicted, and continue to afflict, the province.

It is by no means being suggested that everyone from the PUL community took an active interest in this period. In fact, there were even some who looked upon what was happening with a certain disregard. Caught up with other concerns that lay beyond politics 
and more interested with the significant and exciting cultural changes that were taking place, some young Protestants would admit that the whole Civil Rights movement was of no real concern to them. Particularly insightful in this sense is the testimony of George 'Geordie' Morrow, who would later be imprisoned for Ulster Volunteer Force activities in the 1970s. Growing up in a working-class Protestant environment, Morrow described how politics initially meant little to him, leading to a certain degree of detachment from, and a default opposition to, what was happening.

Politics to me, 1968, would have only been...me and my mates, all we were interested in was music...going down to Smithfield, stopping into the record shops, listening to music. I think...no it [the Civil Rights movement] didn't mean anything to us. $^{23}$

Not everyone was so detached as the young Morrow. His trajectory from youthful disinterest to later paramilitarism reflects the way the majority of the PUL community was very much caught up in seismic events, with responses ranging from outright opposition through to active sympathy. Personified by the words and actions of Ian Paisley, a section of the PUL community wholeheartedly opposed the Civil Rights movement. Seeing bodies like the Northern Ireland Civil Rights Association (NICRA) and the PD as none other than a front for the IRA, Paisley and his supporters not only voiced their opposition but actively engaged in counter-protests aimed at thwarting any progress of the movement. Their vociferous opposition to the Civil Rights cause created significant difficulties for Terence O'Neill, who found himself caught, and eventually destroyed politically, between the demands of the movement and pressure from within Unionism to avoid conceding too much ground.

This raises the base-line Unionist response to civil rights, as demonstrated by thenStormont Minister for Home Affairs William Craig, who told an English journalist just over thirty years later: 'To me it was the beginning of a republican campaign organized entirely by the IRA and it was much more significant than any previous campaign. It was a deliberate effort by the IRA to play a bigger part in the politics of Northern Ireland and the Irish Republic'. ${ }^{24}$ In the words of another Unionist who lived through the era, civil rights appeared a devious, underhand pretense calling for 'British rights for British citizens but secretly intending to raise "the national question" and promote revolution'. ${ }^{25}$ This is the hard-line Unionist stance on civil rights agitation: that it was an IRA plot posing a threat to the existence of the state itself. It was a view echoed many times by the late Rev. Ian 
Paisley, whose later cooperation and magnanimity with leaders of Irish nationalism contrasted with the ideology of 'Paisleyism's' emotive, sectarian rejection of civil rights in any form (Bruce, Wallace \& Taylor 1986). It is connectedly worth framing 'Paisleyism' as part of the 'backlash' against civil rights movements globally, with Richard Nixon's 1968 US Presidential election victory (tapping into discontent of the 'silent majority' of Americans, with white patriotic appeals and law and order emphasis), the assassinations of both Martin Luther King and Bobby Kennedy in 1968, the return to power of conservative icon de Gaulle in France, and the radical Right 'Rivers of Blood' speech by Tory MP for Wolverhampton Enoch Powell (later to journey over to Northern Ireland as MP for South Down). In a recent paper Brian Hanley has convincingly argued that Paisley's success in mobilizing support among ordinary loyalists by denouncing moves towards reform by Prime Minister O'Neill can also be viewed as contiguous with this international 'backlash', with the comparison compounded by the way Paisley's publications carried articles by Right wing American clergyman (including Bob Spencer) opposed to Martin Luther King. ${ }^{26}$

Debate continues over the presence of hard-core Republican elements in the Civil Rights movement. ${ }^{27}$ However, whether or not this is true - authorities on the civil rights movement point out that communists and IRA elements involved tended to urge restraint when it came to protests ${ }^{28}$ - the fact that such sentiments were present within the Protestant community characterised some of the most significant opposition to the Civil Rights movement and was an important contributing factor in defining the atmosphere at the time. Half a century later, this interpretation persists within the PUL community. For example, Nelson McCausland recounted his revealing insight about the NICRA banner carried on the first ever Civil Rights march between Coalisland and Dungannon on 24 August 1968:

There is a significance in the fact that the banner under which they marched, the NICRA banner, was actually carried on each side by one man on each side and both men were members of the IRA. Is there not something significant and symbolic about a NICRA banner carried by two IRA men and in the middle under the banner the Nationalist party, Republican Labour and Labour? ${ }^{29}$

Not all PUL perspectives are so clear cut. There was a certain section of this community that was willing to contemplate the necessity of changes. However, despite a degree of sympathy, such perspectives could be described as 'torn'. For some, the movement's exclusive focus on one side of the community meant that they wrestled with 
the possibility of getting involved. This, for example, was a sentiment expressed in the testimony of a Protestant Queen's University student at the time:

We basically were scared to go [...] because we felt that we didn't understand. We felt it was kind of a march for Catholics, about Catholic rights. We were on the side of it, but we didn't feel that we had any depth of knowledge about it. ${ }^{30}$

The late Hugh Smyth, a long-time Belfast City councillor for the Shankill area from 1971 until his death in 2014, also recalled such a conundrum, with an ultimate decision determined by the associations of militant Irish nationalists. In a common perspective, the 'hijacking' of the civil rights movement by these elements proved ultimately fatal to the involvement of such Protestant working-class men and women:

When that first movement came out now, I would have been saying, "See everything they're saying, I agree with it." I believe in good housing. My mother reared nine of us in a two-bed house, and yet I would have been looked at as a privileged Protestant living in the Woodvale Road of Shankill. We had to convert our dining room to accommodate us. We had to put a screener in the bedroom to divide the girls from the boys. So all those things that they were fighting for, l'd have been fighting for. I would have nearly walked in that march - and then the Republicans took it over with the Tricolours. The Civil Rights movement was a good movement. It was a sincere movement, the people who devoted their time and energy to it were sincere. But, unfortunately, the Republicans seen it as an opportunity and they took it over. ${ }^{31}$

Another loyalist working-class Protestant leader based in Derry/Londonderry agreed that whereas Catholics could demonstrate against the state and 'do something about their lot', the Protestant working-class

couldn't afford to bring down the institutions or the establishment, so we had to suffer our poverty in silence. Because the alternative to what we had, a United Ireland run by the Roman Catholic Church, was a bigger fear - that was worse to us than our poverty. ${ }^{32}$

Similarly, some members of the Northern Ireland Labour Party, including former Stormont representatives David Bleakley and Billy Boyd, were sceptical about being involved in the civil rights campaign, while other Protestants in the NILP like Charles Brett, Samuel Napier, and Tom Boyd were broadly supportive. ${ }^{33}$ Such divisions reflect a diversity that once again highlights the complexity of the Protestant relationship with the civil rights movement. The 'torn perspective' was equally present in the testimony of a former Ulster Unionist councillor, as he shared his recollection of the 9 October march that saw students enter the fray and would lead to the creation of the PD: 
I was in the city centre that day. I was down just wandering about, and I went and watched and listened to the Paisley rally. And I went up to Queens later on and I was talking to some of the people who'd been sitting down there. But that day, I was drawn in two ways. I was listening to Paisley at the front of the City Hall and a wee bit of me was standing around of the back of the city or sitting around the back of the city hall too. So, I suppose it was approaching the apocalypse. I was recognising my doubts about so many aspects of traditional unionism. ${ }^{34}$

The final category includes those that could be described as 'active sympathisers'. It should be remembered that at the first meeting of the Northern Ireland Civil Rights Association on 29 January 1967 at the International Hotel in Belfast, one of the central ideas promoted was that Protestants would be encouraged to join the protests, which were to be broad-based and careful not to antagonize Unionist opinion. A former chair of Queen's University Belfast's Young Unionists, Robin Cole, was duly co-opted onto NICRA's first committee a few days later, while another Unionist, Senator Nelson Elder, attended the function at the International Hotel with one hundred others. ${ }^{35}$ Other Protestants were heavily involved, with some playing quite prominent roles. In both the case of NICRA and the PD, there was, particularly in the early stages, an explicit attempt to forge a movement that would allow the participation of members from across the divide. Paul Arthur described the (perhaps naïve) non-sectarian perspective that dominated in the early days:

We were also, of course, full of the smugness and arrogance of youth, where we were convinced that uniting the Catholic and Protestant working class, no problem. It can be done, we'll do it. And so, we started out with all of this. ${ }^{36}$

Whilst someone like Maurice Mills may well reject that this was the case and that any Protestants that got involved were, as he described, 'sleepy individuals', ${ }^{37}$ it is clear that there was a certain level of cross-community involvement. In a view echoing the late lawyer and human rights activist Kevin Boyle (who came from a Newry Catholic background), Fergus Woods explained:

When it came to the point where the civil rights movement started and I got involved, one of the things that really appealed to me about it was that it didn't seem to be sectarian. You didn't seem to have to be Republican, Unionist or whatever. In the early days of the civil rights marches, people on the march came from every political party except the DUP. Now that really appealed to me; this idea that this was overarching and it wasn't sectarian and it wasn't to do with flags or anthems or anything. It was simply to do with human rights. ${ }^{38}$ 
Erskine Holmes outlined how he was able to feel comfortable within the Civil Rights movement up until a certain point, confirming the idea that in the early days, there was as strong non-sectarian thread that encouraged participation from across society:

There was a turning point for me when I was attending a meeting with colleagues from the civil rights executive. And [Irish Taoiseach] Jack Lynch made a speech which is commonly referred to as "We will not stand idly by" [sic] speech. So, it clearly, at that point in time, I certainly realised that while I wanted full British standards, full British rights, that's not what my colleagues wanted. They had an aspiration for a nationalist Ireland. And they saw events producing this. So, shortly after that, I bowed out of the civil rights movement whenever I saw that that was the general direction that the movement was going. ${ }^{39}$

Also reflective of many 'liberal' Protestants was a future Political Director of the Northern Ireland Office, who, as a Queen's University student, found himself 'in general agreement' with the civil rights campaign and more concerned about the rise of Paisley in the mid1960s. Thus:

following the authorities' controversial, and ultimately violent, response to a civil rights march in Londonderry on 5 October 1968, I joined hundreds of Catholic students, and a substantial number of Protestant students, on two similar marches from the university campus to Belfast city centre in the days that followed. ${ }^{40}$

Equally reflective was this same individual's disappearance from street politics as the situation deteriorated and disturbances increased in the following months.

It could therefore be argued that the early stages of the movement successfully provided the grounds for people from right across Northern Irish society concerned with the broad issue of Civil Rights, regardless of one's background, to become involved. This may help to explain why the movement included the participation of people from the PUL community. The ripples of this were felt in a future generation of political leaders like the Progressive Unionist Party's David Ervine, whose father Walter - a big influence on his son's socialist politics and future dissent from traditional Unionism - was a supporter of the movement, ${ }^{41}$ and also in Ervine's sister-in-law Linda, who since the mid-2010s has organized Irish language initiatives in east Belfast. Linda Ervine often reflects on being inspired by her father Terry Bruton and his brother Barry, who were members of the NICRA and 'wanted to change things in $\mathrm{NI}$ for the better'. ${ }^{42}$ In another case, Eddie Spence, brother of Ulster Volunteer Force leader and Loyalist icon Augustus 'Gusty' Spence, was reportedly present on the first Civil Rights Association march and the seminal 5 October 1968 march 
that opened this article. Though the Spence clan has been described as possessing an 'unusually diverse range of political opinions', ${ }^{43}$ Civil Rights were capable of prompting such divisions within Protestant families, once again highlighting the complexity of the civil rights issue in Northern Ireland and especially within Protestant communities.

Finally, it is worth pointing out that some of those from this community were more than mere 'foot soldiers'. ${ }^{44}$ In addition to those already mentioned, one could point to figures such as the late Edwina Stewart, ${ }^{45}$ Paul Bew, ${ }^{46}$ or Betty Sinclair whose involvement was anything but marginal. A Communist educated at Moscow's International Lenin School, Sinclair (1910-1981) is interesting because she held actual memories of the violence of the 1920s in Ireland, and so was especially cautious about the civil rights marches of the 1960s developing too militant a character. As Sinclair wrote in her diary on 19 October 1968: 'What is wanted is a cool appraisal of the situation and, above all, that civil rights must be won for the whole working class of $\mathrm{NI}$ - Catholic and Protestant. If we fail to make that clear - we will be sectarian in our approach. ${ }^{\prime 47}$ By March 1969 she had resigned from the NICRA executive in protest at the Association green lighting a perceived provocative People's Democracy march. The same organization's representatives replaced her on the executive, and by the summer Northern Ireland faced its most serious communal violence in a generation. Having lived through the shipyard expulsions of July 1920, Sinclair lived to hear of shipyard expulsions in June $1970 .{ }^{48}$

Perhaps one of the most iconic examples of prominent Protestant involvement is that of Ivan Cooper. Originally hailing from a Unionist mercantile background - via the Northern Ireland Labour Party - Cooper was unquestionably a leading light of the Civil Rights movement, and would later go on to play a major role in founding and drafting the early formative documents of the Social Democratic and Labour Party. ${ }^{49}$ But it was his work on the Derry Citizens' Action Committee, as alluded to by a 2016 interview, which most rekindles his proudest political memory and positive association with civil rights agitation:

It was a constant changing of scene. Every day was a different challenge. Exciting, excitement. What happened in Duke Street on the 5th of October was a tragedy, but the whole kaleidoscope of things, they were so exciting, stimulating, exciting. Alas, we're all old men and there's bugger all we can do about it - but for my part, it was the most exciting, exhilarating period of my life..$^{50}$ 
With the Civil Rights movement shown not to be an exclusively Catholic phenomenon, marginalised Protestant perspectives are crucial in helping us to understand what happened. Making them part of how the story is told and remembered is a fundamental requirement in helping prevent such past events from perpetuating the divisions that define Northern Irish society. In order to do so, we must look closely at modes of remembering in the specific context of the province.

\section{From antagonism to cosmopolitanism: Managing the past in Northern Ireland} The field of memory studies has grown exponentially over the course of the last three decades. ${ }^{51}$ This 'memory boom' has led to a rich and varied international literature that straddles a wide range of disciplines and shows no signs of abating. ${ }^{52}$ Given the importance of the past in Northern Ireland, it is hardly surprising that memory has become a prevalent strand of research into this part of the world, as can be evidenced by the range of studies published in recent years. ${ }^{53}$ The surge in all things memory has been accompanied by a proliferation of memory 'modes' that have further enriched and helped spread the reach and interest in this field. ${ }^{54} \mathrm{~A}$ recent addition to this ever-growing list is central to the present project and discussion: agonistic memory.

Chantal Mouffe's seminal and wide-ranging work on cultural identity and its impact on politics has underpinned and been extended in Cento Bull and Hansen's recent study into the notion of 'agonistic memory'. ${ }^{55}$ Mouffe's thesis outlines how politics has moved from what she describes as an 'antagonistic' mode to one of 'cosmopolitanism'. Arguing that this transition has failed to overcome the negative forces it sought to combat, she proposes a move to a model based on agonism. For Mouffe, the context of $20^{\text {th }}$ century nationalism that had brought Europe to its knees via global conflicts was one that encouraged what she calls an antagonistic discourse. This approach was very much based on the notion of 'us vs them' that ultimately created the grounds for the abyss that the world was pulled back from in 1945. In the aftermath of this second global conflict, there was a desire and a move to break away from this model of antagonism and instead try to build, via transnational institutions and drawing on the importance of human rights, a model based on what is described as cosmopolitanism. This new model sought to build a consensus that would enable a degree of harmony and unity. However, Mouffe believes that this quest for consensus has ultimately led to a system that avoids a necessary component - the 
adversary, which she describes as a 'crucial category for democratic politics' ${ }^{56}$ By evading the difficult questions that are faced by modern-day society, the cosmopolitan approach has essentially left such challenging issues to be picked up and instrumentalised by forces on the extremes of the political spectrum. Such forces have subsequently used the sensitivities of these issues to stir up the antagonism that this model was supposed to eradicate. The upshot has been that cosmopolitanism, far from replacing the antagonism of the past with a more harmonious model, has instead provided the grounds for its resurgence. Applied to the European context for example, Mouffe argues that the failings of cosmopolitanism can help us partly understand the current and ongoing frailties of the European project. ${ }^{57}$ In order to overcome this, she argues, an agonistic approach is required. Before explaining what this means, let us first turn to Cento Bull and Hansen's work and how it maps these notions of antagonism and cosmopolitanism.

In their 2016 article 'On Agonistic Memory', Cento Bull and Hansen effectively apply Mouffe's work to the field of memory studies, with a particular focus on the case of Europe. They argue that, as part of the model of politics that dominated prior to the post-war era, the prevalent mode of remembering was also one based on antagonism where memories of the past were used to bolster the 'us vs them' binary. The transition from antagonism to cosmopolitanism, they argue, was replicated from a memory perspective, as a consensual, universalising mode of remembering became the dominant practice. Like Mouffe, they argue that this prevalent cosmopolitan mode of remembering has failed in its objective of eradicating antagonism and has in fact encouraged it. The quest for a consensual narrative that placates everyone has meant that certain, challenging issues of the past have been avoided with the aim of reducing the tension they risk exposing. By avoiding such difficult areas of Europe's inherently contested past, these problematic issues have been left to the extremes who have successfully exploited the associated febrile sentiments in order to undermine the stability of the European project. ${ }^{58}$ Just as Mouffe has proposed the necessity of an approach based on agonism, so to do Cento Bull and Hansen, arguing that in order to break the impasse the European project faces and remove the possibility for the past to create the antagonism that has been such a challenge, a new mode of agonistic remembering is required.

In his studies into collective memory, Halbwachs argues that memories are not set in stone but are in fact subject to change as determined by the needs of the present. ${ }^{59}$ It 
follows therefore that when significant contextual changes occur, just how important moments in the past are remembered can and does shift also. In the case of Northern Ireland, it is possible to demonstrate, via the example of the events of 1968 , how an important contextual shift has been pivotal in bringing about a change that fits the antagonistic to cosmopolitan transition as discussed above.

The onset of the Troubles in the aftermath of the Civil Rights movement was largely responsible for setting up what could be described as an antagonistic mode for remembering this period (and others). Given the nature of the conflict that afflicted the province between 1968 and 1998, it is unsurprising that a fragmented narrative of what happened emerged. The divisions that separated the population and which lie at the root of the problems infiltrated every aspect of life, including how the past was remembered. As a result, the past was used to enhance and consolidate the antagonism that so defined the conflict. ${ }^{60}$ In the case of the events of 1968 , this meant that alternative narratives on what happened, why and who was responsible, became anchored within each community and were used to further consolidate the divisions. Both sides were able to take these events and apply their own reading to justify their stance in the subsequent Troubles. ${ }^{61}$ Crudely speaking, the CNR community could argue that their peaceful attempts at bringing about equality met with brutal repression and therefore left them with no other option than the turn to violence. ${ }^{62}$ Ulster Loyalists, as the working-class, militant embodiment of the 'PUL' community, on the other hand could argue that the Civil Rights campaign marked but the latest attempt by Republicans to advance their objectives and threatened the very existence of the Northern Irish state, thus warranting their violent response. Only with the end of structured violence has a change to this been possible.

As a result of the Peace Process, many things have changed in Northern Ireland, most of which can be seen as positive. In particular, there have been a raft of socioeconomic, political and cultural developments that simply would have been unthinkable during the 1968-98 era. ${ }^{63}$ Such a window of opportunity has also been opened in terms of dealing with the legacy of the past, as exemplified by the case of 1968 . The initial peacetime commemoration of these events took place on the $40^{\text {th }}$ anniversary in 2008 . For the first time there was a genuine attempt to mark the anniversary of the Civil Rights movement, which in itself was an indication of how contextual changes permitted a new approach to discussing the past. ${ }^{64}$ This anniversary signalled a progressive step forward 
through the increased participation of people who experienced these events first hand. However, despite this unquestionably positive change, it is argued here that what happened was in fact a step away from the antagonistic approach and a move towards cosmopolitanism. The laudable objectives of the dominant threads of the $40^{\text {th }}$ anniversary commemoration of 1968, drawing in particular on issues around the place of victims and the importance of human rights, are not in question. However, such an approach that sought to arrive at some sort of consensual narrative through the evasion of some quite difficult questions, and the marginalisation of certain perspectives, is in fact indicative of the more general (and failed) approach that has been taken to dealing with the past since the onset of peace in 1998.

The difficulty and limitations of this transition from conflict to post-conflict is reflected in how National Museums Northern Ireland (NMNI) has approached its treatment of the Troubles. During the conflict, Belfast's Ulster Museum, perhaps understandably, generally avoided confronting the interpretive challenges presented by the dominant antagonistic discourse around the Troubles, focusing instead on re-examining earlier historical periods that have left a significant cultural and political legacy. In the aftermath of the onset of peace in 1998, the museum opened a new temporary exhibition in 2003 entitled Conflict: The Irish at War, which explored the theme of conflict from prehistoric times through to the Troubles. Critically well-received, the exhibition ran for three years until 2006 when the museum closed for major refurbishment. Re-opening in 2009, the new suite of galleries featured one dedicated to the Troubles; it was the first time that the 'conflict' had been given its own dedicated space. However, and very much in keeping with the limitations discussed above in terms of the cosmopolitan approach, this was widely regarded as a regression in terms of the institution's ability to deal with the difficult legacy of the past. It was characterised by an absence of original objects, instead relying exclusively on photographs, presenting, in effect, a version of the conflict as seen through the lens of photojournalists. It was, as one visitor described, “a cop-out - a definite case of 'don't mention the war'" ${ }^{65}$ However, NMNI's approach to dealing with the Troubles must not be considered in isolation; it is but the reflection of the more general cautiousness to such a sensitive issue that risked undermining the Peace Process as it bedded in. Over twenty years on since the Good Friday Agreement, it is becoming increasingly clear that such restraint needs to be dropped. 
The current fragility of the Northern Ireland peace process is attributable to different factors. One of the stand-out themes defining the impasse is the inability of the political elite to come up with and agree on a strategy for dealing with the past. ${ }^{66}$ The only thing that is agreed upon is the need to put in place effective mechanisms to handle this most difficult of issues, to help provide the conditions for a less-divided future. Such is the significance of the issue, it has become as much a central priority for the London and Dublin governments as the local political parties. This explains a whole plethora of initiatives and projects that have stemmed from the political process. ${ }^{67}$ To date, nothing has been successful. There can be no question that the cosmopolitanism of the post-1998 era has been a step in the right direction. However, in keeping with the theories of Mouffe, Cento Bull and Hansen, this consensus-driven approach has in fact led to important questions and perspectives being avoided and marginalised. ${ }^{68}$ As a result, the most challenging areas of Northern Ireland's contested past, arguably avoided by the political elite, have been taken up by elements on the extremes who have been very effective in tapping into the related tensions and sensitivities to help undermine political cooperation and agreement, which, in part, accounts for perennial crises and divisiveness. ${ }^{69}$

\section{8 and the agnostic turn}

In Mouffe's assessment, cosmopolitanism, by attempting to negate the existence of difference in the quest for consensus, is not only impossible, it is also a facilitator of antagonism. Friction, contestation and difference are all fundamental properties of the political process. Any attempt to avoid them mistakenly seeks to remove the vital component that is the 'other'. As she argues, in order to progress we need to:

[G]ive up the dream of a rational consensus as well as the fantasy that we could escape from our human form of life. In our desire for a total grasp, says Wittgentein, "we have got on the slippery ice where there is no friction and so in a certain sense the conditions are ideal, but also, just because of that, we are unable to walk: so we need friction. Back to the rough ground?"70

For Mouffe, the removal of this friction is simply not achievable and instead leaves sensitive and difficult questions to be picked up and manipulated by those who seeks to undermine the system. Such a self-defeating model needs to be replaced, she argues, by one based on 'agonism'. This approach, contrary to the negation of difference actually seeks to make it part and parcel of the political process. Instead of fleeing the tensions created by 
contestation, an agonistic model would provide the grounds for such tensions to be a constructive part of the process where multiple perspectives are encouraged, creating what she describes as a 'conflictual consensus'. ${ }^{71}$

Cento Bull and Hansen argue in favour of a move to a mode of remembering based on agonism where there would be no attempt to search for a one-size-fits-all, consensual perspective of the past, for such a thing is simply not possible. ${ }^{72}$ Instead, and contrary to the hitherto dominant model that sought to create a single master-narrative, 'agonistic memory is multivocal and multiperspectivist, aiming not at achieving consensus but at recognising conflict and agency'. ${ }^{73}$ This 'multiperspectivity' provides the grounds for and facilitates the co-existence of contesting narratives of the past through a self-reflexive acceptance of the complexity of how such memories are constructed including the importance of passions in such a process. Using the example of the $50^{\text {th }}$ anniversary of the 1968 events, the remainder of this article will analyse the applicability of agonism to dealing with the legacy of the past in Northern Ireland and argue that the incorporation of Protestant perspectives, as evident in 2018 , demonstrates the timeliness and effectives of an agonistic approach.

Amongst the wide-ranging material produced to coincide with the $50^{\text {th }}$ anniversary, there were a number of projects that have arguably embraced a more agonistic approach, seeking in particular to move away from this period being considered an exclusively 'Catholic Story'. For example, the 50 ${ }^{\text {th }}$ Anniversary of Civil Rights Committee 1968, set out the following objectives:

The Committee has adopted the Community Relations Council and Heritage Lottery Fund Principles for commemorations which starts with historical facts; recognises the implications and consequences of what happened; understands that different perceptions and interpretations exist; deepens understandings of the civil rights period and all in the context of an inclusive and accepting society. The Civil Rights Committee will be engaging in constructive dialogue with those who did not, or do not, share the views of the Civil Rights movement. ${ }^{74}$

Such indisputably agonistic principles were equally evident in some of the events in their programme that facilitated the cross-community dialogue sought. ${ }^{75}$ Other bodies have also been involved in events and activities that certainly suggest a trend towards a more inclusive response, bringing the Protestant perspective in from the cold. ${ }^{76} \mathrm{It}$ is however, the example of an extensive project at Belfast's Ulster Museum that most evidently and explicitly demonstrates the effectiveness of the agonistic approach. 
Following the 2015 publication of Sous les pavés...The Troubles, the academic Dr Chris Reynolds entered into a collaboration with William Blair of National Museums Northern Ireland (NMNI) with the objective of incorporating the findings of his monograph into the treatment of Northern Ireland's 1968 in the galleries of the Ulster Museum. This project has evolved in four phases. ${ }^{77}$ Firstly, minor interventions were made to encourage a broader historical contextualisation, with a specific emphasis on the international context. The second stage saw a significant overhaul of gallery material and the incorporation of interactive content, focussing in particular on the use of filmed testimonies conducted with protagonists from the time. An educational programme was formulated in collaboration with the national curriculum development and examination board for Northern Ireland (CCEA), leading to several study days hosted at the Ulster Museum and the creation of a set of online resources for use in the classroom. ${ }^{78}$ The third stage saw the formulation of a programme to mark the $50^{\text {th }}$ anniversary of the events. An extended temporary exhibition entitled 'Voices of 68' was curated and hosted at the Ulster Museum and accompanied by a 3-day conference, led by a range of the project interviewees. ${ }^{79} \mathrm{~A}$ number touring versions of 'Voices of 68 ' was conceived and travelled to almost 40 destinations in Ireland, the UK, Europe and the US. ${ }^{80} \mathrm{~A}$ digital version was also created to further facilitate the geographical reach of the exhibition material. ${ }^{81}$ The fourth and final stage saw the incorporation of the 'Voices of 68' exhibition into the permanent gallery of the Ulster Museum. The expansion, success and effectiveness of this project can largely be explained by the combination of oral history and agonism that underscored its approach.

There are many characteristics of this project that fit the paradigm as defined by Cento Bull and Hansen and others. ${ }^{82}$ In terms of the argument being made in this article, the stand-out characteristic of the approach underpinning the 1968 project has been the drive to go beyond the inclusion of the 'usual suspects' ${ }^{83}$ The methodological approach of oral history has facilitated the inclusion of a wide range of voices in how this story is told. There is no suggestion here that the use of oral history is without its limitations and criticisms. Indeed, one must be wary of taking testimonies at face value and be cognisant of the intricate relationship between the fluidity of memory and the subsequent impact on how individual recollections of the past are selected and reworked. ${ }^{84}$ As Halbwachs and others have argued, our memories are very much determined by the present and one must take such factors into consideration when dealing with oral history. ${ }^{85}$ However, with such caveats 
in mind, the general effectiveness of the oral history approach is well-established ${ }^{86}$ Its use has become an important element in peacebuilding efforts in post-conflict societies around the world ${ }^{87}$ Proponents highlight how its use facilitates the construction of a much more inclusive narrative of the past, encouraging dialogue that is able to bring in hitherto marginalised perspectives as one of its principal advantages in such difficult contexts. ${ }^{88}$ Herein lies the explanation for its relevance not only for this particular project but also for the broader challenge of dealing with legacy issues as part of the peace process. One only has to consider the great breadth of grassroots activities in Northern Ireland that are built around the use of oral history to take stock of its significance within this particular context. ${ }^{89}$ Such recognition of its effectiveness in helping overcome the challenge of managing the legacy of the past has also been reflected in government initiatives. For example, the 2014 Stormont House Agreement, which set out recommendations for confronting legacy issues, proposed the creation of an Oral History Archive as one potential mechanism. ${ }^{90}$ In both academic circles and amongst the general public, this proposal has been welcomed. ${ }^{91}$

The Ulster Museum 1968 project includes voices of those (and in particular from the Protestant perspective) who until now have been marginalised from the construction of the memory of this period. All sides have been included and the range of activities (effective and diverse digital content, study days, conferences, travelling and permanent exhibitions) have created opportunities for alternative narratives to meet, thus encouraging 'agonistic contamination'.$^{92}$ This multi-perspectivity through the use of oral history interviews has helped create an inclusive space for all voices to be heard and the passions from each side to be given the room to breathe. In addition, the explicit focus on exploring, broadening and deepening the context of this period (with a particular emphasis on the exceptional international circumstances of the 1960s) has helped encourage a stronger consideration of the socio-political circumstances that were central to what happened and why. Finally, the distillation of these characteristics into an effective study programme, explicitly linked to the national curriculum, has encouraged 'an ethos of openness instead of prioritizing one narrative' amongst those that will be responsible for sculpting the nature of future memories. ${ }^{93}$

\section{Impact and Reaction}


A long-term view is required before the full impact can realistically be delineated. However, there are a certain number of elements that can be cited that would suggest that this project and its approach has provided a range of potential lessons that could be applied to the broader question of the province's difficult past. Throughout there has been a conscious effort to solicit feedback from all those involved and to integrate their recommendations into the iterative process that has been central to how the collaboration has evolved. This has included listening carefully to what interviewees, school pupils, teachers and even an external evaluation body have had to say. ${ }^{94}$ Such (broadly positive) feedback has helped enhance the agonistic approach. One could also cite the strong engagement of project interviewees that has included people from right across the cross-section of Northern Irish society and has seen them give up their time for interviews, study days, conferences as well donating material to the museum's collection. The effectiveness of the approach has been recognised as an example of good practice by commissioners of the Flags, Identity, Culture and Tradition (FICT) initiative. ${ }^{95}$ The underpinning approach of the 1968 project has also been influential in terms of its influence on NMNI curatorial policy and, in particular, regarding its increasingly prominent role as a central actor in the challenge of dealing with the legacy of the past. NMNI CEO and Director Kathryn Thompson outlined the impact of the project as follows:

This project was based on collecting oral histories and using those testimonies to pose question and therefore help people explore different perspectives and we think that this is what has been really important to us and the methodology which has been developed is something we would like to look at repeating for potentially other years or other key events. ${ }^{96}$

Furthermore, in response to the 2018 public consultation on 'Addressing the Legacy of Northern Ireland's Past', the NMNI submission placed the 1968 project front and centre, citing it as an example of how:

[...] it is more important that multiple perspectives are represented, and groups of people or communities see their narrative included which in turn enhances their capacity for narrative hospitality towards alternative perspectives. We would argue therefore that a more discerning and critical approach is included in structuring the Oral History Archive, that rather than acting only as a repository, people could record their experiences in a more meaningful way and invest in something that has wider application. This would present much greater opportunities for effective dialogue. ${ }^{97}$ 
Finally, as well as converging with - and influencing - emergent public and museum policy, examples of the project's feedback also underscore the readiness amongst the general public for such an agonistic approach. It is first of all important to recognise that not everyone is enamoured with the multi-perspective approach, as exemplified by the examples below:

I feel that it was very insensitive to include DUP members criticising the events that history agrees were valid and necessary events; Too heavy on the extreme Loyalist/Unionist side. Gregory Campbell? Nelson McCausalnd??; It may trigger people's emotions who lived through the Troubles; Gregory Campbell equating his family being poor with the systematic oppression of Catholics was particularly offensive; This is also a very difficult and upsetting topic; Honestly, I was deeply disturbed by the insensitivities of some of the speakers today. ${ }^{98}$

However, the more common sentiment, as demonstrated below, has been a willingness and a recognition to accept opposing perspectives:

I know that in Northern Ireland this is very difficult as the divisions are so deep. It is a living experience over many years with hatred and bitterness. [...] there will never be a consensus. But we need to dialogue and listen to each other to prevent the bitterness and divisions being passed to another generation and try to come to some sense as to why things happened. ${ }^{99}$

Many visitors explained the benefits of the multivocality that underpinned the 'Voices of 68' exhibition:

So important to recognise people recall it through different perspectives; [...] an example that nothing is black and white and that we should always look at every side to see how it all influenced events; No war is over until you know the stories of the other sides; It is of utmost importance to record multiple and conflicting perspectives so that an objective view of history may be retained. ${ }^{100}$

Such positive reactions were not limited to general visitor feedback. School pupils visiting the exhibition as part of the education programme also recognised the advantages of hearing contested perspectives:

It let me see both sides of the civil rights; I sort of knew like there was a lot of opposing sides but not so much what the sides were standing for if that makes sense; Hearing other people's stories helped me to understand it better; People from different backgrounds have different views; Shows it wasn't just Catholics involved; It was good to hear all the different people's perspectives on the troubles. ${ }^{101}$ 
The overall sense from the feedback garnered, and as eloquently outlined below, is a recognition that whilst confronting such conflicted narratives is difficult, it is a necessary step forward and one that the general public genuinely seems ready and willing to take:

The exhibition at the Ulster Museum is unsettling - being confronted by some narratives about ' 68 that you believe are wrong. But that is the point and it is quite discomforting. However, I think there will be quite a few people who will disregard the totality of the exhibition for this reason. That would be a shame. One has to be prepared to listen to other viewpoints. I think that the material should be the start of a critical debate as to what did happen. Museums can be great spaces for this type of learning. ${ }^{102}$

\section{Conclusion}

The agonistic approach of the 1968 project at the Ulster Museum has provided an example of the way Protestant perspectives of this period can be brought in from the cold and become part of the way in which the story is told, and the memory constructed. The effectiveness of the approach in recalibrating a more inclusive, constructive and progressive memory of this pivotal moment in the province's recent past has been outlined. Furthermore, this project consolidates the argument that museums are 'uniquely positioned' to provide agonistic spaces to help post-conflict societies deal with the challenges of managing the past. ${ }^{103}$ Herein lies its broader significance.

It is proposed that this theoretical and methodological approach provides a potentially effective blueprint that could be applied to dealing with the broader challenge of the legacy of past as part of the Northern Irish Peace Process. The toolkit used has been effective because it has embraced the reality of Northern Ireland's contested past. It could be argued that agonism has defined the Peace Process itself: the Good Friday agreement of 1998 did not solve the problems of Northern Ireland. ${ }^{104}$ The same broad divide that determined the nature of the conflict during the Troubles is still very much in place today. Peace came about not as a result of resolution, but instead due to the recognition that the time had come to accept that differences existed and that something had to be done to provide the basis for such differences to co-exist (and would avoid the continuation of sectarian violence). Since the onset of peace, a cosmopolitan approach to the past has sought overcome the antagonism of the Troubles era. However, and in keeping with inadequacies of such an approach as outlined by Mouffe and Cento Bull and Hansen, such cosmopolitanism explains the inability of the Peace Process to effectively manage the legacy 
of the past and has led to it becoming one of the main stumbling blocks preventing progress. The importance of 1968 is not only related to the effectiveness of this project. The $50^{\text {th }}$ anniversary of this year effectively marks the beginning of a whole succession of very difficult, Troubles-related anniversaries to come. More so than ever, an effective strategy to manage the legacy of the past and confront the expected commemorative turbulence is vitally important to ensure the past is longer used to perpetuate the divisions of Northern Irish society and further weaken an already fragile Peace Process. It is argued here that such a strategy should be based on an agonistic approach.

\footnotetext{
${ }^{1}$ Purdie, Politics in the Streets, 146; McCann, War and an Irish Town, 99.

2 The phrase "1968" has come to mean much more than the calendar year one would immediately think of. In fact, these four digits are today understood as something much broader, complex and intriguing. They represent a period that goes beyond the obvious twelve months to incorporate a longer timespan, stretching from the mid-1960s to the mid1970 s when, across the globe, country after country was rocked by a wave of protest. A wealth of academic literature on this topic exists. Some examples include, Fraser, 1968; Gassert and Klimke, 1968 - Memories and Legacies; Katsiaficas, Imagination of the New Left; Tismaneanu, Promises of 1968; Klimke and Scharloth, 1968 in Europe; ZancariniFournel, Les luttes et les rêves, 778-865.

${ }^{3}$ For a more detailed analysis of this period see Purdie, Politics in the Streets; Prince, Northern Ireland's '68; Reynolds, Sous les pavés...the Troubles.

${ }^{4}$ Eagan and McCormack, Burntollet.

${ }^{5}$ One only has to consider the consistent use of 1968 as the starting point for recent histories of the province. Also noteworthy in this sense is the 2008 BBC documentary looking at the events of 5 October 1968 and its title The Day the Troubles Began.

${ }^{6}$ The crudeness of this three-way definition of one community is acknowledged but nevertheless provides a pertinent manner in the context of this piece to capture the various strands within one side of the divide In Northern Ireland.

7 Purdie, Politics in the Streets; McCluskey, Up Off Their Knees, Appendix 1; Ó Dochartaigh, Ulster's White Negroes.

${ }^{8}$ In perhaps the best - and certainly most detached - study of discrimination, John Whyte determined that the Unionist government did preside over certain 'unfair' practices and was guilty of gerrymandering local government boundaries to maintain Unionist power and influence (especially in Derry/Londonderry). While not as pronounced as made out, discrimination in public employment and housing was commonplace, in particular - again in the region west of the River Bann. Whyte, "How much discrimination was there under the unionist regime," 31.

${ }^{9}$ Reynolds, "Northern Ireland's 1968 in a Post-Troubles Context," 638-40.

${ }^{10}$ See Caute, Year of the Barricades; Fink, Gassert and Junker, 1968; Cornilis and Waters, Memories of 1968; Dreyfus-Armand, Les Années 68.

${ }^{11}$ Reynolds, "Northern Ireland's 1968 in a Post-Troubles Context," 641-3.

12 Reynolds, Sous les pavés...the Troubles, 194-201.
} 
13 Irish News, February 12, 2008, 10.

${ }^{14}$ It should be pointed out the $40^{\text {th }}$ anniversary committee also included historian Henry Patterson and writer Anne Devlin. Patterson is a Protestant from a Workers' Party background (with what some perceive as a present Unionist tilt), while Devlin - despite being the daughter of a founder of the SDLP - identifies more as a feminist and is not an SDLP member.

${ }^{15}$ Interview with Bernadette McAliskey, Dungannon, July 18, 2009.

${ }^{16}$ Interview with Austin Currie, Maynooth, February 16, 2010.

17 Ivan Cooper, quoted in Irish News, January 29, 2008, 11.

18 Interview with Denis Haughey, Cookstown, May 16, 2009.

${ }^{19}$ Conference website: http://www.nicivilrights.org/events/international-civil-rightsconference-derry-4-5-october-2008/; "Civil rights programme launched." Derry Journal, September 25, 2008.

20 The 'Spirit of 68', Conference held on November 22, 2008 in Sandinos, Derry.

21 Interview with Pádraigín Drinan, Belfast, October 31, 2008.

${ }^{22}$ Again, the crudeness of this three-way definition of one community is acknowledged but nevertheless provides a pertinent manner in the context of this piece to capture the various strands within one side of the divide In Northern Ireland.

${ }^{23}$ Interview with George Morrow, Cultra, April 28, 2017.

${ }^{24}$ Quoted in Taylor, Loyalists, 52.

${ }^{25}$ Garland, "Who can legitimately claim NICRA," 2.

${ }^{26}$ Hanley, "Civil Rights Internationally," 7-8. Paisley travelled to the United States in the spring of 1968, his third American speaking tour, visiting over twenty churches in nineteen states. He had originally been awarded a doctorate by the whites-only Bob Jones University in South Carolina.

${ }^{27}$ Recent examples of exchanges on this question highlight a general acceptance of the presence of IRA elements in and around the periphery of the Civil Rights movement, but continued debate as to the extent of their roles and influence. See, for example, O'Doherty, "Civil Rights Movement"; Walker, "Eyewitness to history"; Kearney, "We have come full circle"; Rodgers, "Is Sinn Fein so ashamed of its past."

${ }^{28}$ The IRA was led at this time by Dubliner Cathal Goulding (1923-1998), who was moving Republicanism steadily leftwards and away from armed actions. It accordingly avoided official representation on NICRA's first executive council, with its members 'keeping order' and stewarding civil rights demonstrations in late-1968. See Purdie, "Was the Civil Rights Movement a Republican/Communist Conspiracy?," 38-39.

29 Interview with Nelson McCausland, Cultra, December 14, 2017.

30 Interview with Carol Tweedale, Cultra, September 20, 2017.

31 Interview with Hugh Smyth, Belfast, February 15, 2012. See also Blood, Watch My Lips, $60-61$.

32 Interview with Glenn Barr, Derry, November 28, 2012.

${ }^{33}$ Irish Times, May 26, 1969, 14; Mulholland, Northern Ireland at the Crossroads, 45. For the NILP see Edwards, "Unionist Derry is Ulster's Panama."

${ }^{34}$ Interview with Chris McGimpsey, Cultra, December 6, 2017.

35 McCluskey, Up Off Their Knees, 104-5. However, Elder walked out of the conference when he failed to win the argument for retaining the death penalty for the murder of policemen, and Cole resigned from the committee in protest at the description of Northern Ireland as a 'fascist state'. 
36 Interview with Paul Arthur, Cultra, June 7, 2016.

37 Interview with Maurice Mills, Ballymoney, October 11, 2016.

38 Interview with Fergus Woods, Cultra, February 24, 2017. For assessment of Boyle's NICRA engagement see Chinoy, Are You With Me, 26-57.

39 Interview with Erskine Holmes, Cultra, July 5, 2016.

40 Maccabe, "Tactics, Strategy, and Space," 121.

${ }^{41}$ See Ervine's comments in Moloney, Voices from the Grave, 316.

${ }^{42}$ Email correspondence with Linda Ervine, April 19, 2020; Ann Marie Hourihane, "Bringing

An Teanga Gaeilge to east Belfast." Irish Times, February 7, 2015, 4.

${ }^{43}$ Sanders, "Problems of Class, Religion and Ethnicity," 95.

${ }^{44}$ Interview with Carol Tweedale, Cultra, September 20, 2017.

${ }^{45}$ See Hyndman, "'Like Mother, Like Daughter," 108-114.

${ }^{46}$ Currently a Crossbench Life peer in the House of Lords, Bew (1950-) was born to a Cork mother and a Belfast Protestant father (both were doctors, with his mother attached to the British Army). Educated at the private Campbell College and Pembroke College, Cambridge University, he moved from Civil Rights associations to eventually act as an adviser to Ulster Unionist leader David Trimble. He was raised in his father's background and has always identified as part of a wider Irish 'Protestant Ascendancy' (Godson, "Ulster's A.J.P. Taylor"). ${ }^{47}$ Quoted in Smylie, "Betty Sinclair," 128.

48 Irish Times, June 30, 1970, 1.

${ }^{49}$ Devlin, Straight Left, 136; McLoughlin, John Hume, 40.

50 Interview with Ivan Cooper, Derry, July 6, 2016. See also Purdie, Politics in the Streets, 140-142, 194-195.

${ }^{51}$ Bell, "Agonistic Democracy," 148; Winter, "The Generation of Memory," 69-92.

${ }^{52}$ For example, Hodgkin and Radstone, Memory, History, Nation; Boyd, "Politics of History and Memory in Democratic Spain"; Cubitt, History and Memory; Phillips, Framing Public Memory; Schwartz, Abraham Lincoln; Nora, "Between Memory and History."

${ }^{53}$ For example, Beiner, Forgetful Remembrance; Campbell, "We Shall Overcome?"; McGrattan and Hopkins, "Memory and Post-Conflict Societies"; Smyth (Ed.), Remembering the Troubles; Brown and Grant, "A Lens Over Conflicted Memory"; McLaughlin, "Stories from the inside"; McDowell and Braniff, Commemoration as Conflict; Viggiani, Talking Stones.

54 Wertsch, Voices of Collective Remembering, 30.

${ }_{55}$ Mouffe, The Democratic Paradox; On the Political; Cento Bull and Hansen, "On agonistic memory."

${ }^{56}$ Mouffe On the Political, 20.

57 Mouffe, "An Agonistic Approach to the Future of Europe."

${ }^{58}$ Cento Bull and Hansen, "On agonistic memory," 393.

${ }^{59}$ Halbwachs Les Cadres Sociaux de la Mémoire; La Mémoire Collective.

60 Beiner, "Between Trauma and Triumphalism."

${ }^{61}$ For example, Kingsley, Londonderry Revisited; Farrell, Twenty Years On.

62 It should be noted here that such an interpretation is largely stereotypical and has become common as a result of the subsequent Troubles and certain elements' attempts to stitch the Civil Rights movement into a narrative justification for the onset of violence. It is, of course, the case that vast swathes of those involved in the Civil Rights movement categorically reject such a narrative and, with some justification, have attempted (without much success) to separate the Civil Rights movement from the Troubles narrative. 
${ }^{63}$ C.f. for example Bairner, "Still taking sides," 215-31.

${ }^{64}$ Reynolds, "Northern Ireland's 1968 in a Post-Troubles Context," 642-3.

65 Meredith, "Minimal Troubles."

${ }^{66}$ Hamber and Kelly, "Practice, Power and Inertia," 24-44.

${ }^{67}$ Such initiatives include the Northern Ireland Office's 2014 Stormont House Agreement, the formation of the Commission on Flags, Identity, Culture and Tradition (FICT) commission in 2016, and the 2018 Northern Ireland Office public consultation on 'Addressing the Legacy of Northern Ireland's Past'.

${ }^{68}$ Examples of such a cosmopolitan, consensus-driven approach could include the 2013 Haass report (https://www.northernireland.gov.uk/publications/haass-report-proposedagreement), or the 2014 Stormont House Agreement

(https://www.gov.uk/government/publications/the-stormont-house-agreement).

${ }^{69}$ See J. Bryson, "Letter: SF talk about human rights yet supported IRA terrorism which denied thousands of people the core right to life." Belfast News Letter, November 29, 2017, 20. Given the duration, death toll and damage of the conflict, there are many, many 'legacy' issues that remain deeply contentious. These include areas such as the role of security forces, justice and accountability and issues relating to 'collusion' (for the most recent work on collusion, see McGovern, Counterinsurgency and Collusion). The Unionist-inclined newspaper the Belfast News Letter went as far as to publish a 'legacy' series in 2018, featuring numerous commentators, with the express purpose of challenging what many Unionists regard as 'imbalance' against British state forces in how the past is officially addressed.

70 Mouffe, "Deliberative Democracy," 750.

${ }^{71}$ Mouffe, "An Agonistic Approach to the Future of Europe," 633.

${ }^{72}$ Cento Bull and Hansen, "On agonistic memory," 400.

${ }^{73}$ Cento Bull, "Working through the violent past," 4.

${ }^{74}$ Pamphlet produced and distributed by the $50^{\text {th }}$ Anniversary of Civil Rights Committee 1968 at their launch event on 25 January 2018 in First Presbyterian Church, Belfast.

75 For example, 'Civil Rights Then and Now - Reconciling Difference'. Belfast 5 February 2018. This event included the participation of the Rev Mervyn Gibson (grand secretary of the Orange Order), Progressive Unionist Party Councillor John Kyle and the Social Democratic and Labour Party's Bríd Rodgers.

${ }^{76}$ See for example BBC Radio Foyle series entitled "68':

https://www.bbc.co.uk/programmes/m0000kdg

${ }^{77}$ Reynolds, "Enduring insularity."

${ }^{78}$ See https://www.nmni.com/learn/1968-history-resource/Home.aspx

79 See https://www.nmni.com/news/voices-of-68-exhibition;

https://www.nmni.com/whats-on/voices-68; https://www.nmni.com/whats-on/1968-andbeyond

${ }^{80}$ The exhibition has been hosted in the following destinations: Ballymena Library; Derry Central Library; Newry Library; Dungannon Library; Derry, Guildhall; Belfast City Hall; Ulster University (Magee Campus); Nottingham Trent University; Irish Cultural Centre, London Hammersmith; Luton Irish Centre; Victoria Gallery \& Museum, Liverpool; University of Bath: November; World Heritage Centre, Manchester; Cardiff University; Cork County Library; Cork City Library; Dublin City Library; Galway, NUIG; Kerry Library; Mayo County Library; Arklow Library; Tipperary County Library; Boston College, USA.

${ }^{81}$ See https://itunes.apple.com/us/book/voices-of-68/id1401984783?ls=1\&mt=11 
82 Van Alstein, "Memory of Peace"; Bell, "Agonistic Democracy and the Politics of Memory."

${ }^{83}$ The following people were interviewed as part of the project: Paul Arthur; Paul Bew; Gregory Campbell; Ivan Cooper; Anthony Coughlan; Austin Currie; Anne Devlin; Michael Farrel; Mervyn Gibson; Denis Haughey; Erskine Holmes; Anne Hope; Judith Jennings; Bernadette McAliskey; Nelson McAusland; Eddie McCamley; Eamonn McCann; Chris McGimpsey; Dympna McGlade; Aidan McKinney; Maurice Mills; Geordie Morrow ; Mike Nesbitt; Hubert Nichol; Henry Patterson; Brid Rodgers; Bríd Ruddy; Carol Tweedale; Eileen Weir; Fergus Woods.

${ }^{84}$ Strangleman, "Portrait of a deindustrializing island."

85 Knauer and Walkowitz, Memory and the Impact of Political Transformation; Olick, "Genre Memories"; Schwartz, "The Social Context of Commemoration"; Halbwachs Les Cadres Sociaux de la Mémoire; La Mémoire Collective.

${ }^{86}$ Della Porta, Methodological Practices; Thompson, Voice of the Past; Portelli, Death of Luigi Trastulli; Frisch, Shared Authority.

${ }^{87}$ For example, Hamber, Transforming Societies; Bickford, "Unofficial Truth Projects"; Schaffer and Smith, "Conjunctions"; Humphrey, Politics of Atrocity and Reconciliation. ${ }^{88}$ For example, Maddison and Diprose, "Conflict dynamics and agonistic dialogue"; Mac Ginty and Richmond, "Local Turn in Peace Building"; Tully, "Recognition and dialogue"; Shopes, "What is History?"; Aras et. al., Documenting and Interpreting Conflict.

89 Hamber and Kelly, "Practice, Power and Inertia."

90 Northern Ireland Office, "The Stormont House Agreement."

${ }^{91}$ Northern Ireland Office, "Addressing the Legacy of Northern Ireland's Past. Analysis of the consultation responses"; Historians and the Stormont House Agreement, "Report on a Workshop Held at Hertford College, Oxford, 19 October 2016."

92 Pozzi, "Museums," 13-14.

93 Bell, "Agonistic Democracy," 161.

94 "Evaluation of 1968 research and interpretation re Collecting the Troubles and Beyond at the Ulster Museum," carried out by Social Research Centre. December 28, 2016. For an analysis of the findings of this evaluation see Reynolds, "Enduring insularity."

${ }^{95}$ Set up in the wake of the 2014 Stormont House Agreement, this body was tasked with writing a report on proposals for how to deal with some of the difficult issues facing the peace process. One such issue is dealing with the past.

96 Interview with Kathryn Thompson (by Josie Richardson), March 19, 2019.

97 NIO, "Addressing the Legacy of Northern Ireland's Past"; NMNI 2019.

98 Visitor feedback on 'Voices of 68' exhibition.

99 Visitor feedback on 'Voices of 68' exhibition.

100 Visitor feedback on 'Voices of 68' exhibition.

${ }^{101}$ Feedback on GCSE study day.

102 Visitor feedback on 'Voices of 68' exhibition.

103 Mouffe, "Museums as Agonistic Spaces."

${ }^{104}$ Strömbom, "Exploring analytical avenues for agonistic peace."

\section{References}


Aras, R., D. Boyd, D., M. M. Clark, M. Kurt, S. M., Mohaqqueq, C. P. Gonzalez Perez, and L. Taminian. Documenting and Interpreting Conflict Through Oral History: A Working Guide. New York: Columbia University, 2012.

Bairner, A. "Still taking sides: sport, leisure and identity." In Northern Ireland After the Troubles?: A Society in Transition, edited by C. Coulter and M. Murray, 215-231. Oxford: Oxford University Press, 2008.

Beiner, G. Forgetful Remembrance: Social Forgetting and Vernacular Historiography of a Rebellion in Ulster. Oxford: Oxford University Press, 2018.

Beiner, G. "Between Trauma and Triumphalism: The Easter Rising, the Somme, and the Crux of Deep Memory in Modern Ireland." Journal of British Studies 46, no. 2 (2007): 366-389.

Bell, D. "Agonistic Democracy and the Politics of Memory." Constellations 15, no. 1 (2008): 148-166.

Bickford, L. “Unofficial Truth Projects.” Human Rights Quarterly 29, no. 4 (2007): 994-1035.

Blood, M. Watch My Lips, I'm Speaking!. Dublin: Gill \& Macmillan, 2007.

Boyd, C. "The Politics of History and Memory in Democratic Spain." The Annals of the American Academy of Political and Social Science 617, no. 1 (2008): 133-48 .

Brown, K. and A. Grant. "A Lens over Conflicted Memory: Surveying 'Troubles' Commemoration in Northern Ireland." Irish Political Studies 31, no. 1 (2016): 139-62.

Bruce, S., R. Wallis, and D. Taylor. "No surrender!": Paisleyism and the Politics of Ethnic Identity in Northern Ireland. Belfast: Department of Social Studies, Queen's University Belfast, 1986. 
Campbell, S. "We Shall Overcome'? The Good Friday/Belfast Agreement and the Memory of the Civil Rights Movement.' Open Library of Humanities 4, no. 1 (2018): 1-25.

Caute, D. The Year of the Barricades; A Journey through 1968. London: HarperCollins, 1990.

Cento Bull, A. "Working through the violent past. Practices of restorative justice through memory and dialogue in Italy." Memory Studies (2018): 1-16.

Cento Bull, A., and H. L. Hansen. "On agonistic memory." Memory Studies 9, no. 4 (2016): 390-404.

Chinoy, M. Are You With Me? Kevin Boyle and the Rise of the Human Rights Movement. Dublin: Lilliput Press, 2020.

Commission on Flags, Identity, Culture and Tradition (FICT). 2016. Website available at: https://www.fictcommission.org/en. Accessed June 15, 2018.

Cornilis, I., and S. Waters, eds. Memories of 1968. International Perspectives. Bern: Peter Lang, 2010.

Cubitt, G. History and Memory. Manchester: Manchester University Press, 2007.

Della Porta, D. Methodological Practices in Social Movement Research. Oxford: Oxford University Press, 2014.

Devlin, P. Straight Left - An Autobiography. Belfast: Blackstaff Press, 1993.

Dreyfus-Armand, G. Les Années 68. Un Monde en Mouvement. Nouveaux Regards sur Une Histoire Plurielle. Paris: Syllepse, 2008.

Eagan, B., and V. McCormack. Burntollet. London: LRS, 1969. 
Edwards, A. “'Unionist Derry is Ulster's Panama': The Northern Ireland Labour Party and the Civil Rights Issue." Irish Political Studies 23, no. 3 (2008): 363-385.

Farrell, M., ed. Twenty Years on. Dingle: Mount Eagle Publications, 1988.

Fink, C., P. Gassert, and D. Junker, eds. 1968: The World Transformed. Washington: Cambridge University Press, 1998.

Fraser, R. 1968: A Student Generation in Revolt. New York: Pantheon, 1988.

Frisch, M. Shared Authority: Essays on the Craft and Meaning of Oral and Public History. Albany: State University of New York Press, 1990.

Garland, R. "Who can legitimately claim NICRA legacy?." Irish News, February 25, 2008, 2.

Gassert, P., and M. Klimke, eds. 1968 - Memories and Legacies of a Global Revolt. Washington: German Historical Institute, 2009.

Godson, D. “Ulster's A. J. P. Taylor gets his just reward." The Spectator, February 24, 2007: 20.

Haass, R. and M. O'Sullivan. An Agreement Among the Parties of the Northern Ireland Executive on Parades, Select Commemorations, and Related Protests; Flags and Emblems; and Contending With the Past. 31 December 2013.

Halbwachs, M. Les Cadres Sociaux de la Mémoire. Paris: Alcan, 1925.

Halbwachs, M. La Mémoire Collective. Paris: Presses universitaire de France, 1950.

Hamber, B. Transforming Societies After Political Violence: Truth, Reconciliation and Mental Health. New York: Springer, 2009. 
Hamber, B., and G. Kelly. "Practice, Power and Inertia: Personal Narrative, Archives and Dealing with the Past in Northern Ireland." Journal of Human Rights Practice 8, no. 1 (2016): $25-44$.

Hanley, B. "Civil Rights Internationally and the Crisis of the 1960s." The Long 60s: Heritage, History \& Memory Project, Workshop No. 2. Belfast: The Fellowship of Messines Association, 2019.

Historians and the Stormont House Agreement. "Report on a Workshop Held at Hertford College, Oxford, 19 October 2016." Accessed June 23, 2018. Available at; http://irishhistoriansinbritain.org/?p=321

Hodgkin, K., and S. Radstone. Memory, History, Nation: Contested Pasts. 4th edition. New Brunswick, NJ: Transaction Publishers, 2012.

Humphrey, M. The Politics of Atrocity and Reconciliation: From Terror to Trauma. London and New York: Routledge, 2002.

Hyndman, M. “Like Mother, Like Daughter: Sadie Menzies, 1914-1996, and Edwina Stewart, 1934-." In Left Lives in $20^{\text {th }}$ Century Ireland, Vol. 3 - Communist Lives, edited by F. Devine and P. Smylie, 105-116. Dublin: Umiskin Press, 2020.

Katsiaficas, G. The Imagination of the New Left: A Global Analysis of 1968. Boston: South End Press, 1987.

Kearney, D. "We have come full circle: Northern Nationalism has politically remobilised." Eamonnmallie.com, January 29, 2018. Accessed June 20, 2018. Available at:

https://eamonnmallie.com/2018/01/come-full-circle-northern-nationalism-politicallyremobilised-declan-kearney/

Kingsley, P. Londonderry Revisited: A Loyalist Analysis of the Civil Rights Controversy. Belfast Publications, 1989. 
Klimke, M. and J. Scharloth. 1968 in Europe. A History of Protest and Activism. New York: Palgrave Macmillan, 2008.

Knauer, L. M., and D. Walkowitz. Memory and the Impact of Political Transformation in Public Space. Durham and London: Duke University Press, 2004.

Maccabe, C. "Tactics, Strategy and Space." In The British and Peace in Northern Ireland: The Process and Practice of Reaching Peace, edited by G. Spencer, 120-146. Cambridge: Cambridge University Press, 2015.

Mac Ginty, R., and O. P. Richmond. "The Local Turn in Peace Building: a critical agenda for peace." Third World Quarterly, 34, no. 5 (2013): 763-783,

Maddison, S., and R. Diprose. "Conflict dynamics and agonistic dialogue on historical violence: a case from Indonesia." Third World Quarterly 39, no. 8 (2018): 1622-1639.

McCann, E. War and an Irish Town. London: Pluto Press, 1993.

McClenaghan, P. Spirit of '68: Beyond the Barricades. Derry: Guildhall Press, 2009.

McCluskey, C. Up Off Their Knees. Dublin: Conn McCluskey and Associates, 1989.

McDowell, S., and M. Braniff. Commemoration as Conflict: Space, Memory and Identity in Peace Processes. Basingstoke: Palgrave Macmillan, 2014.

McGovern, M. Counterinsurgency and Collusion in Northern Ireland. London: Pluto Press, 2019.

McGrattan, C. and S. Hopkins. "Memory and Post-Conflict Societies: From Contestation to Integration?" Ethnopolitics 16, no. 5 (2017): 488-499. 
McLaughlin, C. "Stories from the Inside: The Prisons Memory Archive." In Post-Conflict Literature: Human Rights, Peace, Justice, edited by C. Andrews and M. McGuire, 68-80. New York: Routledge, 2016.

McLoughlin, P. J. John Hume and the Revision of the Irish Nationalism. Manchester: Manchester University Press, 2010.

Meredith, F. “Minimal Troubles at Ulster Museum.” The Irish Times, October 24, 2009.

Moloney, E., ed. Voices From the Grave: Two Men's War in Ireland. London: Faber and Faber, 2010.

Mouffe, C. "An Agonistic Approach to the Future of Europe." New Literary History 43 (2012): 629-640.

Mouffe, C. “Museums as Agonistic Spaces', Artforum 48, no. 10 (2010): 326-330.

Mouffe, C. On the Political. London: Routledge, 2005.

Mouffe, C. The Democratic Paradox. London: Verso, 2000.

Mouffe, C. "Deliberative Democracy or Agonistic Pluralism?" Social Research 66, no. 3, (Fall 1999): 745-758.

Mulholland, M. Northern Ireland at the Crossroads: Ulster Unionism in the O'Neill Years, 1960-9. Basingstoke: Macmillan, 2000.

Nora, P. "Between Memory and History: Les Lieux de Mémoire." Representations 26 (1989): $7-24$. 
Northern Ireland Office (NIO). "The Stormont House Agreement." 2014. Accessed June 28, 2018. Available at: https://www.gov.uk/government/publications/the-stormont-houseagreement

Northern Ireland Office (NIO). "Addressing the Legacy of Northern Ireland's Past." May 2018. Accessed June 28, 2018. Available at:

https://www.gov.uk/government/consultations/addressing-the-legacy-of-northernirelands-past

Northern Ireland Office (NIO). “Addressing the Legacy of Northern Ireland's Past. Analysis of the consultation responses." July 2019. Accessed July 8, 2019. Available at:

https://assets.publishing.service.gov.uk/government/uploads/system/uploads/attachment data/file/814805/Addressing the Legacy of the Past Analysis of the consultation responses.pdf

Ó Dochartaigh, F. Ulster's White Negroes: From Civil Rights to Insurrection. Edinburgh: AK Press, 1994.

O'Doherty, M. "The Civil Rights Movement and the role of the IRA." Presentation to Public Record Office of Northern Ireland, 13 November 2019. Accessed November 25, 2019. Available at: $\underline{\text { https://www.nidirect.gov.uk/articles/civil-rights-movement-and-role-ira }}$

Olick, J. K. "Genre Memories and Memory Genres: A Dialogical Analysis of May 8, 1945 Commemorations in the Federal Republic of Germany." American Sociological Review 64, no. 3 (1999): 381-402.

Phillips, K. R. Framing Public Memory. Alabama: University of Alabama Press, 2004.

Portelli, A. The Death of Luigi Trastulli, and Other Stories: Form and Meaning in Oral History. Albany: State University of New York Press, 1991. 
Pozzi, C. "Museums as Agonistic Spaces." In European Museums in the $21^{\text {st }}$ Century: Setting the Framework. Vol. 1. Milan: Politecnico di Milano, 2011.

Prince, S. Northern Ireland's 68. Civil Rights, Global Revolt and the Origins of the Troubles. Dublin: Irish Academic Press, 2007.

Purdie, B. "Was the Civil Rights Movement a Republican/Communist Conspiracy?." Irish Political Studies 3 (1988): 33-41.

Purdie, B. Politics in the Streets: The Origins of the Civil Rights Movement in Northern Ireland. Belfast: Blackstaff Press, 1990.

Reynolds, C. Sous les pavés...the Troubles. Northern Ireland, France and the European Collective memory of 1968. Bern: Peter Lang, 2015.

Reynolds, C. “Northern Ireland's 1968 in a Post-Troubles Context." Interventions 19, no. 5 (2017): 631-645.

Reynolds, C. "Enduring insularity and the memory of Northern Ireland's 1968." In Heritage after Conflict. Northern Ireland, edited by E. Crooke and T. Maguire, 16-33. Abingdon, Routledge, 2018.

Rodgers, B. "Is Sinn Fein so ashamed of its own past that it has to rewrite It?" Eamonnmallie.com, February 1, 2018. Accessed June 21, 2018. Available at: https://eamonnmallie.com/2018/02/sinn-fein-ashamed-past-rewrite-brid-rodgers/

Sanders, A. "Problems of Class, Religion and Ethnicity: A Study of the Relationship Between Irish Republicans and the Protestant Working Class During the Ulster "Troubles" 19691994." Irish Political Studies 24, no. 1 (2009): 89-105.

Schaffer, K., and S. Smith. "Conjunctions: Life Narratives in the Field of Human Rights." Biography 27, no. 1 (2004): 1-24. 
Schwartz, B. Abraham Lincoln and the Forge of National Memory. Chicago: University of Chicago Press, 2000.

Schwartz, B. "The Social Context of Commemoration: A Study in Collective Memory." Social Forces 61, no. 2 (1982): 374-402.

Shopes, L. "What Is Oral History?" From the Making Sense of Evidence series on History Matters: The U.S. Survey on the Web [2002]. Accessed October 3, 2019. Available at: http://historymatters.gmu.edu

Smylie, P. "Betty Sinclair." In Studies in Irish Radical Leadership: Lives on the Left, edited by E. O'Connor and J. Cunningham, 121-134. Manchester: Manchester University Press.

Smyth, J., ed. Remembering the Troubles: Contesting the Recent Past in Northern Ireland. Indiana: University of Notre Dame Press, 2017.

Strangleman, T. "Portrait of a deindustrializing island." In Revisiting Divisions of Labour: The Impact and Legacies on a Modern Classic, edited by G. Crow, and J. Ellis, 55-68. Manchester: Manchester University Press.

Strömbom, L. "Exploring analytical avenues for agonistic peace." Journal of International Relations and Development (2019). Accessed March 2, 2020. Available online: https://doi.org/10.1057/s41268-019-00176-6

Taylor, P. Loyalists. London. Bloomsbury, 1999.

Thompson, P. The Voice of the Past: Oral History. New York. Oxford University Press, 1988.

Tismaneanu, V., ed. Promises of 1968: Crisis, Illusion and Utopia. Budapest: Central European Press, 2011. 
Tully, J. "Recognition and dialogue: the emergence of a new field." Critical Review of International Social and Political Philosophy 7, no. 3 (2004): 84-106.

Van Alstein, M. "The Memory of Peace." In Philosophy of War and Peace, edited by D. Praet, 149-160. Gent: International Philosophy Olympiad, 2016.

Viggiani, E. Talking Stones: The Politics of Memorialization in Post-Conflict in Northern Ireland. New York: Berghahn Books, 2014.

Walker, B. M. "Eyewitness to history: IRA leaders key role in undermining civil rights movement." Belfast Telegraph, September 4, 2019, 21.

Wertsch, J. V. Voices of Collective Remembering. New York: Cambridge University Press, 2002.

Whyte, J. "How much discrimination was there under the unionist regime, 1921-1968?" In Contemporary Irish Studies, edited by T. Gallagher and J. O'Connell, 1-36. Manchester: Manchester University Press.

Winter, J. "The Generation of Memory: Reflections on the "Memory Boom"." Contemporary Historical Studies: Bulletin of the German Historical Institute 27 (2000): 69-92.

Zancarini-Fournel, M. Les luttes et les rêves. Une histoire populaire de la France. De 1685 à nos jours. Paris: Zones, 2016. 